\title{
The Politics of Public Debt: Neoliberalism, Capitalist Development and the Restructur- ing of the State
}

Wolfgang Streeck

Max Planck Institute for the Study of Societies

\begin{abstract}
Rising public debt has been widespread in democratic-capitalist political economies since the 1970s, generally accompanied among other things by weak economic growth, rising unemployment, increasing inequality, growing tax resistance, and declining political participation. Following an initial period of fiscal consolidation in the 1990s, public debt took an unprecedented leap in reponse to the Great Recession. Renewed consolidation efforts, under the pressure of 'financial markets', point to a general decline in state expenditure, particularly discretionary and investment expenditure, and of extensive retrenchment and privatization of state functions.
\end{abstract}

JEL classification: $H 1, H 2, H 5, H 6$.

Keywords: Democracy; capitalism; neoliberalism; fiscal crisis; privatization; consolidation.

\section{MPIfG Journal Article \\ Wolfgang Streeck: The Politics of Public Debt: Neoliberalism, Capitalist Development and the Restructuring of the State. In: German \\ The original publication is available at the publisher's web site: $h \mathrm{ttp}: / / \mathrm{dx}$.doi.org/10.1111/geer.12032 \\ 1. INTRODUCTION \\ The MPIfG Journal Articles series features articles by MPIfG researchers and visiting scholars published in peer-reviewed journals. \\ Max Planck Institute for the Study of Societies (MPIfG) Cologne | www.mpifg.de}

From the 1970s on, public debt increased more or less steadily in most, if not all, OECD countries as never before in peacetime. ${ }^{1}$ The rapid rise in public indebtedness was a general, not a national phenomenon. Yet, in some countries, especially ones with low levels of inflation like West Germany, this rise began earlier than in others (Streeck, 2011). In this essay, I will emphasize the crossnational commonalities rather than the national specifics of the transformation of the 'tax state' (Schumpeter, 1991 [1918]) into a debt state, and from there to the present consolidation state. ${ }^{2}$ My argument focuses on the family of countries that adopted a regime of democratic capitalism, or capitalist democracy, after the Second World War, combining institutionalized mass participation in government with a market economy and capitalist property relations. By placing the current fiscal crisis of democratic-capitalist political economies into a historical context - in other words, treating it as a step in a historical sequence, not as a single event - I hope to shed light on the underlying dynamics of the crisis, adding a new perspective to what static-technical theories of public finance have to offer.

1. I am indebted to my doctoral students Lukas Haffert, Philip Mehrtens, and Daniel Mertens for constructive comments and suggestions, and to Lea Elsässer for faithful collection and processing of my statistical data.

2. For an elaboration see Streeck (2013, 164ff., passim). 
The historical context within which I will situate the fiscal crisis of contemporary democratic states I conceive as a process of capitalist development. By this I mean in particular the neoliberal revolution which began in the 1970s and essentially abolished the 'mixed economies' (Shonfield, 1965; Shonfield and Shonfield, 1984) of the three postwar decades, resulting in a more or less continuously growing role of markets including international markets in political-economic governance. In line with Schumpeter's early research program of 'fiscal sociology' (Schumpeter, 1991 [1918]), I will discuss public finance as both an indicator of and a causal factor in an evolving relationship between political rule and the economy, or more precisely, between the democratic state and modern capitalism. ${ }^{3}$ Approaching this paper's subject - the politics of public debt - in this way, I will show that political-economic theories in the tradition of Public Choice, which attribute the rise in government debt to an inherent tendency of democracies to 'live beyond their means', cannot account for the fiscal crisis of today. Having rejected what I call the democratic failure theory, and based on the records of the last four decades, I will present a list of proximate causes accounting for the rise in state indebtedness and relate them to what I consider, for the purposes of my narrative, the ultimate cause behind them. That cause, I will argue, is the long-term decline in the growth performance of advanced capitalist economies and their subsequent inability to honor the promises of economic and human progress on which their legitimacy depended. ${ }^{4}$

Following my analysis of the genealogy of the current crisis of public finance, I will turn to the five years that have passed since the near-crash of the global financial system in 2008, to outline what I perceive to be a new politics of debt management by consolidation. As I will argue, this includes a profound restructuring of the democratic-capitalist political economy in continuation of the neoliberal transformation of the last two decades of the twentieth century in the direction of a state that is 'leaner', less interventionist and, in particular, less receptive to popular demands for redistribution than was the case for states of the postwar period. ${ }^{5}$ Special attention will be paid to the relationship between the politics of government debt on the one hand and social and economic inequality on the other.

\section{DEMOCRATIC FAILURE?}

Historically, democratic capitalism is a recent phenomenon. It became firmly institutionalized as a political regime only after 1945 under the international hegemony of the New Deal in the United States and, in Europe, on social democratic traditions (for many others Judt, 2005, 2009; Reich, 2007; Ruggie, 1982).

3. 'The public finances are one of the best starting points for an investigation of society, especially but not exclusively of its political life. The full fruitfulness of this approach is seen particularly at those turning points, or epochs, during which existing forms begin to die off and to change into something new. This is true both of the causal significance of fiscal policy (insofar as fiscal events are important elements in the causation of all change) and of the symptomatic significance (insofar as everything that happens has its fiscal reflection).' (Schumpeter, 1991 [1918], 110).

4. For the purpose of this approach, I will consider declining growth as exogenous.

5. This is essentially what Pierson $(1998,2001)$ refers to as an 'austerity regime'. 


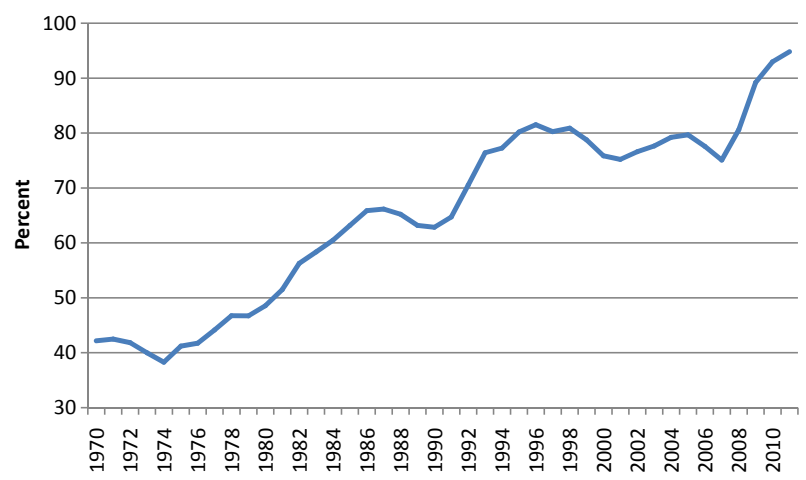

Figure 1 Government debt as a percentage of GDP, selected OECD countries, 1970-2011

Notes: Countries included in unweighted average: Austria, Belgium, Canada, France, Germany, Italy, Japan, the Netherlands, Norway, Sweden, UK, USA

Source: OECD economic outlook: Statistics and projections (Database)

In democratic capitalism, or capitalist democracy, governments are expected to intervene in markets to secure social justice and stability as defined and demanded by a voting majority. The underlying assumption is that without political correction of a Keynesian and Beveridgean kind, markets tend to give rise to cumulative advantage, also known as the 'Matthew effect' (Merton, 1968), which would make them unacceptable to a democratically empowered citizenry. $^{6}$

Average public indebtedness among OECD countries more than doubled in the roughly four decades between the 1970s and 2010 from about $40 \%$ of GDP to more than $90 \%$ (for a sample of 12 major OECD countries, see Figure 1). Increasing public debt was a general phenomenon in almost all countries of democratic capitalism. Differences between countries did exist, but from a longitudinal perspective they reduce mostly to time lags and appear to be of minor significance in the light of the universal nature of the process. Note that the rise of indebtedness was halted in the mid-1990s for about a decade, to resume only in 2008, the first year of an apparently never-ending financial crisis when state indebtedness started its steepest incline of the period under observation. I will return to this later.

Economic-institutionalist theories in the tradition of writers like James Buchanan attribute the increase in public debt since the 1970s to an inherent tendency of political democracy to overspend, caused by the short-sightedness of voters and the opportunism of politicians (Buchanan, 1958; Buchanan and Tullock, 1962, 1977; Buchanan and Wagner, 1977). Where Public Choice transmutes into a theory of democratic failure, the claim is that public deficits and public debt are

6. In other words, democratic capitalism implies a politics with a redistributive, egalitarian bent; indeed with reference to the postwar political formation in the West one could just as well speak of egalitarian capitalism (Kenworthy, 2007). One implication is that not every political interference with market outcomes is 'democratic' as the term is used here; for example, for the Bush tax cuts to be passed, democracy as we know it had to be neutralized rather than activated. 


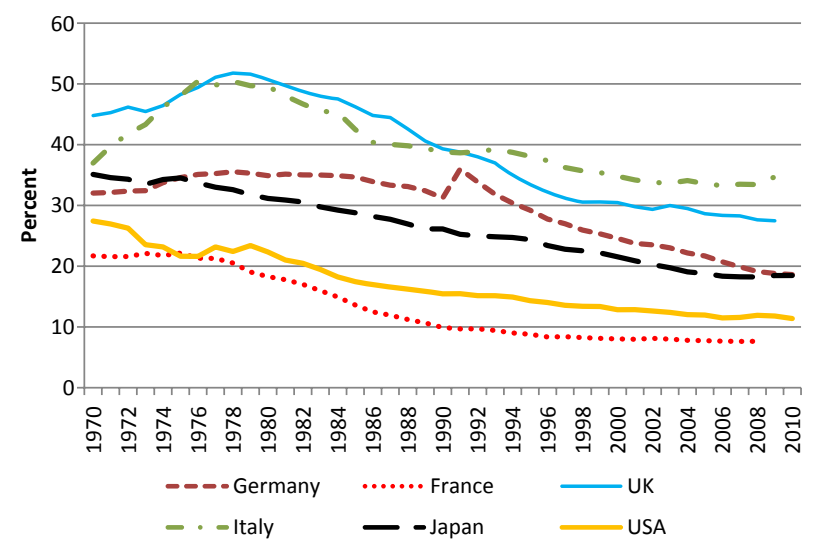

Figure 2 Union density rates, six countries, 1960-2010

Source: Amsterdam Institute for Advanced Labour Studies: ICTWSS Database 3, May 2011

due to majoritarian electoral pressure from below for redistribution through public spending. In the following, I will argue that this account, based on highly stylized hypothetical assumptions on 'rational' behavior under democratic conditions, appears highly improbable, to say the least, when the increase in public debt is placed in the context of other events and developments that happened in the OECD world during the same period. This is because the growth of public debt was accompanied by a steady decline in both democratic mobilization and the distributional position of mass publics, pointing to a secular contraction of the power resources and redistributive capacities of the very democratic politics held responsible by theories of 'public choice' for the rise in public indebtedness since the 1970s.

As to democratic power resources, participation in national elections in the OECD world peaked in the 1960s when it was as high as $84 \%$ on average for 22 countries. From there, it dropped continuously from decade to decade and reached 73\% in the 11 years from 2000 to 2011 (Schäfer and Streeck, 2013). Unionization attained its highest postwar level in the 1970s and then began to fall everywhere (for six major countries see Figure 2). ${ }^{7}$ A third form of mass political participation, 'industrial action', also known as strikes, practically ended in the 1980s (see Figure 3, which omits Italy where strikes were extremely frequent in the 1970s, but ceased almost entirely in the 1980s).

The decay of popular participation in redistributive politics was reflected in, or associated with, a continuous loss in the distributional position of popular majorities. Unemployment increased everywhere as governments withdrew from the postwar promise of politically guaranteed full employment. Today, unem-

7. Figure 2 does not include Sweden where union density was traditionally the highest in the world. Including it would have distorted the scale. Apart from this, the Swedish trajectory was very much inline with the other countries, except that the decline started later. At the beginning of the 1990s, union density in Sweden was still above 80\%; by 2011, in about two decades, it had fallen to $68 \%$. 


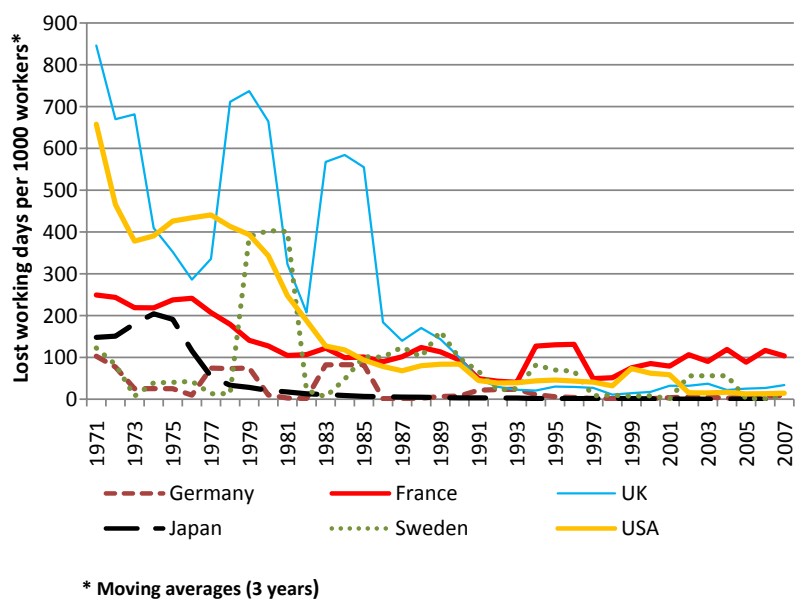

Figure 3 Volume of industrial action, six countries, 1971-2007

Source: ILO Labour Statistics; US Bureau of Labor Statistics

ployment rates between five per cent and ten per cent are considered normal in capitalist democracies, de-unionization and often painful 'reforms' of social security systems notwithstanding. ${ }^{8}$ Even Sweden, the classical country of full employment policy, has since the end of the 1990s been content with a 'natural' level of unemployment hovering between six per cent and nine per cent (Mehrtens, 2013). In parallel, income inequality steadily increased in most countries up to the middle of the first decade of the 2000s (Figure 4). One factor behind this was a massive decline of the wage share almost everywhere (Duménil and Lévy, 2004; Kristal, 2010; Ryner, 2012) caused by a lasting decoupling of wage increases from increases in productivity. This development was, not surprisingly, most pronounced in the United States, where by the end of the 1970s average hourly earnings had ceased to develop in line with productivity, embarking on a long period of stagnation while productivity continued to rise. Increases in household incomes during the period in question were solely due to higher participation of women in the labor market (Kochan, 2013; Figure 5). ${ }^{9}$

Summing up, the rise of public debt - the arrival of the debt state - was part of a neoliberal revolution in the postwar political economy. At a time when democratic redistributive intervention in capitalist markets became ineffectual on many fronts, it is unlikely that the increasing public debt can be explained by voters and workers exercising superior political power. Indeed rather than electorates extracting unearned incomes from the economy, growing government indebtedness in OECD nations was accompanied by a lasting decline in both living conditions and the distributional position of popular majorities,

8. The average rate of unemployment in the OECD was $2.2 \%$ from 1960 to 1973 , from where it increased steadily to $7.1 \%$ in $1990-2001$. From 2002 to 2008 , it was at $5.8 \%$, only to rise to $6.6 \%$ between 2009 and 2012.

9. Kochan refers to the historical watershed of the late 1970s as to the breaking of the postwar 'social contract' (Kochan, 2013). 


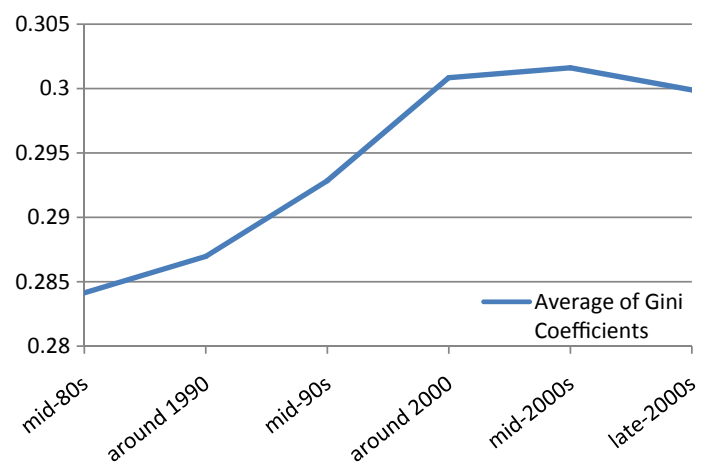

Figure 4 Income inequality in selected OECD countries, 1980s to 2000s

Notes: Included in the unweighted average: Austria, Belgium, Canada, Denmark, Finland, France, Germany, Greece, Ireland, Italy, Japan, the Netherlands, Norway, Portugal, Spain, Sweden, UK, USA Source: OECD income distribution (Database) - Inequality

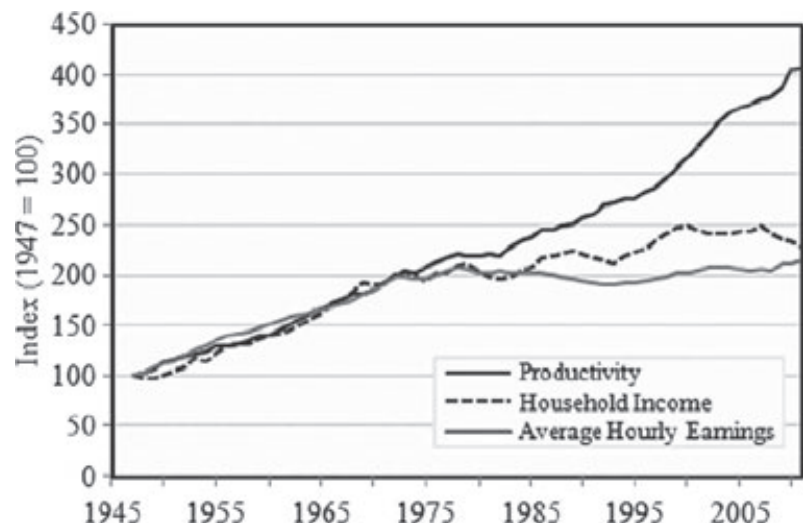

Figure 5 United States: The broken social contract, 1947-2011

Source: Kochan, (2013), based on data from the Bureau of Labor Statistics and the Economic Policy Institute

which in turn was associated with a secular decay in the power resources (Korpi, 1983) of redistributive democracy.

\section{PROXIMATE CAUSES, ULTimATE CAUSE}

To account for the increase in government debt across a wide range of countries over an extended period of time, it seems useful to draw on the proven distinction between proximate and ultimate causes (Thierry, 2005). The parallel build-up of debt in capitalist democracies was produced by a variety of specific factors that, while often interrelated, differed between countries and over time. All of these proximate causes, however, point back to one common, ultimate cause, which is a secular 
decline in economic growth in the democratic-capitalist OECD world. ${ }^{10}$ In other words, I argue that the accumulation of public debt since the 1970s must be understood as one element among others of a variegated response of countries and actors to declining growth and to the pressures on the politics of rich capitalist democracies that resulted from it.

The following, incomplete list includes some of the most important proximate causes of the rise of public debt during the period in question.

1. Public debt began to increase in the mid-1970s, and in particular in the early 1980 s as a result of an OECD-wide recession which activated automatic fiscal stabilizers and, in some countries, called forth 'Keynesian' stimulus spending. The 'Second Oil Crisis' in 1979 caused higher spending on unemployment benefit and active labor market policies while lowering public revenues, especially from payroll taxes. The same was true for the contraction of employment following the deflationary monetarist policy of the US central bank under Volcker after 1979, with interest rates at times exceeding 20\%, and the British turn to monetarism under Margaret Thatcher. Generally, the revocation of the postwar commitment to politically guaranteed full employment a commitment that had caused high and rising inflation after the end of postwar growth - and the acceptance on the part of governments of a residual level of unemployment as a natural condition was bound to put pressure on public finance as long as retrenchment of the postwar welfare state had not yet been accomplished.

2. The end of both growth and inflation led to a sharp increase in tax resistance, first in the United States and then elsewhere in the OECD world. In response, several countries passed tax reforms to end what is called 'bracket creep': the movement of tax payers into higher income tax rates with rising nominal incomes. In subsequent years, 'globalization' and the resulting international tax competition (Genschel and Schwarz, 2013) motivated tax cuts for high income earners and corporations. ${ }^{11}$ Emblematic for this was the tax reform during Ronald Reagan's first period of office (1981-85), which together with deflation and an unprecedented arms build-up was instrumental in causing the most dramatic rise in government debt since the Second World War (Greider, 1981; Stockman, 1986). While tax revenue had until the mid-1970s by and large kept pace with public spending, by the late 1980 s it began to stagnate until it started declining after the end of the century (Figure 6). By 2010, taxation levels were back where they had been two decades earlier.

3. The 1990s was a time when OECD nations managed to bring down public spending in an effort to match it to by and large stagnant public revenues (cf. Figure 6). In part, this was made easier by the end of the Communist bloc and the 'peace dividend' it carried with it. But it was also due to deep reforms of welfare state institutions. It seems reasonable to consider welfare state reform as a time-lagged response to the rise in social spending after the end of politically guaranteed unemployment. Retrenchment of social protection was

10. On the central importance of growth for the performance of contemporary capitalist economies see Holtfrerich (2007).

11. For Europe, see Schratzenstaller (2011). 


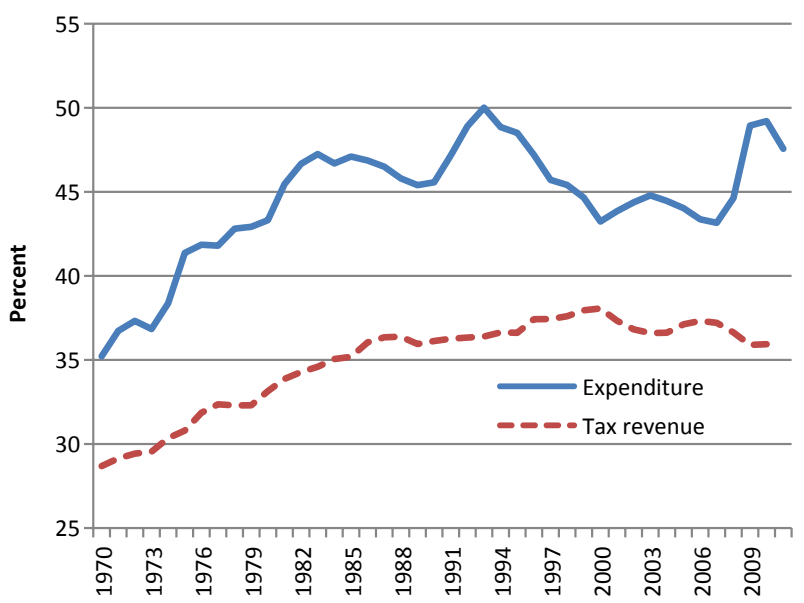

Figure 6 Government expenditure and total tax revenue as a percentage of GDP, selected OECD countries, 1970-2011

Notes: Countries included in unweighted average: Australia, Austria, Belgium, Canada, Denmark, Finland, France, Germany, Greece, Italy, Japan, the Netherlands, Norway, Portugal, Spain, Sweden, Switzerland, UK, USA. Government expenditure, Portugal from 1977, Greece from 1980, Switzerland and Ireland from 1990

Source: OECD Tax Revenue Database, OECD Economic Outlook: Statistics and Projections (Database)

championed in particular by the Clinton administration which, following its defeat in the mid-term elections of 1994, vowed to 'end welfare as we know it'. $^{12}$ In Germany, welfare reform was delayed by unification as the West German social policy regime was translated one-to-one to the Neue Laender (Streeck and Trampusch, 2006). A decade later, the social democratic Schröder government passed the so-called Hartz IV legislation. Depending on the country, welfare state reform did not always and necessarily result in lower aggregate spending, at least not immediately; it did, however, cut entitlements per case in reaction to rising numbers of long-term unemployed and other recipients of social assistance. The 1990s, which may be described as a first period of fiscal consolidation, show that mass democracies, if placed under enough economic pressure and with voters sufficiently demobilized, are quite capable of curtailing social protection and generally imposing economic hardship on a majority of voters in the interest of 'sound finance'.

4. By the late 1990s, a country like the United States had achieved a budget surplus (Pierson, 1998, 2001). This did not last long, however, as it was soon to be wiped out after 2001 by deep tax cuts combined with a steep increase in military spending, very much on the model of the first Reagan administration. Given that the 'Bush tax cuts', as they came to be called, overwhelmingly

12. The Clinton administration's turn to welfare reform was a response to the failure of its initial project to restore economic growth by restoring American competitiveness in manufacturing, among other things by better training of the US workforce. See the memoirs of Clinton's first Secretary of Labor, Robert Reich (1997). 


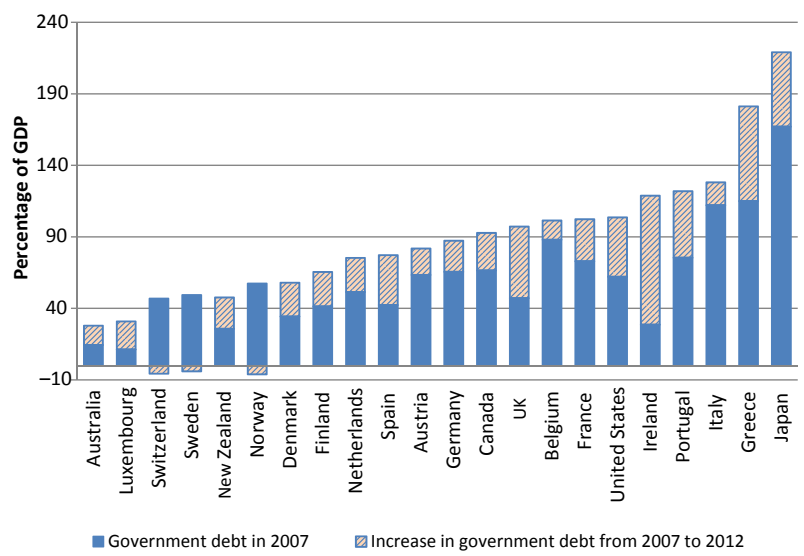

Figure 7 Increase in government debt during the financial crisis

Source: OECD Economic Outlook, Statistics and Projections (Database)

benefited corporations and the very rich (Hacker and Pierson, 2011), they cannot possibly be attributed to an excess of redistributive democracy. ${ }^{13}$ Quite to the contrary, the restored public deficit was used as an argument for further cuts in public expenditure, as military spending was untouchable and higher taxes on high incomes politically infeasible. Current debates on balancing the US federal budget continue to focus almost exclusively on the so-called 'entitlements', in particular to social security and healthcare. Generating a public deficit by simultaneously cutting taxes and raising military spending corresponds to the strategic concept of the ultra-liberal American Right as organized by the antitax activist Grover Norquist. The strategy is summed up in the slogan, 'starving the beast', the beast being the residual welfare state of the postNew Deal United States. ${ }^{14}$

5. The financial crisis of 2008 caused the greatest ever hike in public indebtedness due to the immense costs of both the rescue of the financial system and the stimulus spending required to keep national economies from collapsing (for a selection of countries see Figure 7). Like tax cuts for the rich, 'Star Wars', and the invasions of Afghanistan and Iraq, the absorption of unsustainable private debt by the public debtor of last resort after 2008 cannot be attributed to irresponsible greed among voters and politicians. ${ }^{15}$ In fact, the emergency measures that

13. Redistribution to the poor had by this time already been privatized, i.e., relocated to deregulated financial markets where citizens were allowed to make up for stagnant incomes by taking out ever riskier loans (Crouch, 2009). After 2008, these ended to a large extent on the public balance sheet.

14. That tax cuts for the well-to-do cause public deficits, which are then used to argue the need for cuts in social welfare spending, is by no means limited to the United States. The same pattern was effective in Europe, including Germany (Schratzenstaller, 2013) where the losses in revenue caused by the Schröder tax reform were for several years the only reason why the federal government was unable to achieve a balanced budget. The deficit later became a central argument for the Hartz reform of the German welfare state.

15. It is a different question whether the deregulation of the financial system, especially in countries like the United States and the United Kingdom, partly in compensation for a neoliberal retrenchment of the state, was an act of reckless negligence on the part of governments. 


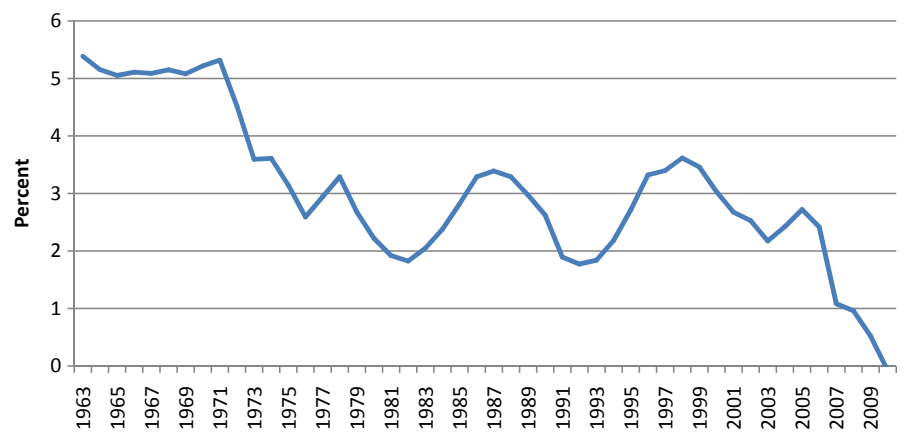

-Growth rates (Five-year moving average)

Figure 8 Annual growth rates of selected OECD countries, 1963-2010

Notes: Countries included in unweighted average: Australia, Austria, Belgium, Canada, Denmark (from 1967), Finland, France, Germany, Greece (from 1971), Ireland, Italy, Japan, the Netherlands, Norway, Portugal, Spain, Sweden, Switzerland (from 1966), United Kingdom, United States Source: OECD Economic Outlook: Statistics and Projections (Database)

were taken in 2008 and later wiped out all of the - politically very costly accomplishments of the consolidation efforts of the 1990s restored the level of public debt to the trend line for the 40-year period beginning in the mid-1970s (cf. Figure 1). Contrary to public choice theory, the most dramatic leap in public indebtedness since the 1970s has been a case of failure, not of democracy but of capitalism, in particular in its new form of financial capitalism.

How are the various proximate causes of the fiscal crisis of rich democracies related? The common ultimate cause, I suggest, behind the various proximate causes effective along the trajectory of the public debt build-up was the declining growth performance of the OECD world (Figure 8). After 1974, average real growth per year in OECD countries over five-year periods fluctuated between two per cent and three per cent, apart from two peaks at the end of the 1980s and the 1990s when it rose to between three per cent and four per cent, albeit only for a short time. Thereafter, in the one-and-a-half decades since 1998, i.e., ten years before the Great Recession, average growth rates declined almost steadily until they bottomed out at zero in 2010. With the end of inflation in the 1980s came the end of the automatic devaluation of public debt. Moreover, average unemployment rates ranged between six per cent and seven per cent during the same period. Low growth after 1998 kept debt ratios high although budget deficits almost disappeared on average during 2002-08 due to consolidation efforts. They were, of course, to come back with a vengeance as a result of the crisis.

Pulling together ultimate cause and proximate causes, weak economic growth induced governments and central banks in the 1970s - with the exception of the Bundesbank after 1974 - to accommodate wage pressures to preserve employment, which resulted in inflation. Monetary stabilization in the 1980s produced unemployment and thereby upset the fiscal balance of social security systems; it also caused tax resistance, which came to be supported by 'globalization' giving rise to tax competition by enabling mobile assets to change between jurisdictions. Globalization also called forth 'supply-side policies' of tax relief for 


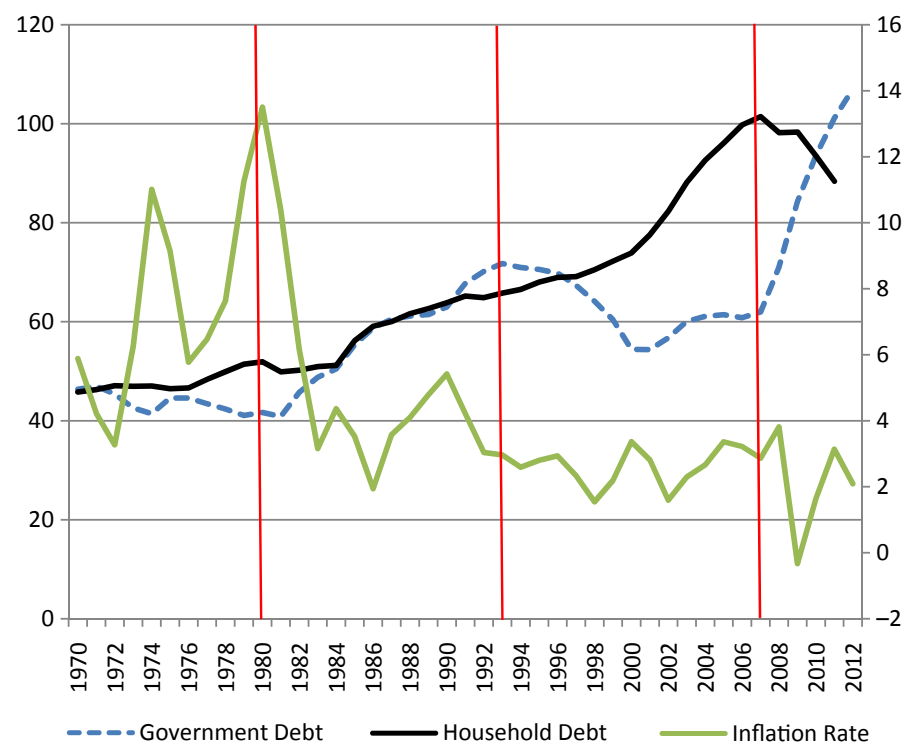

Figure 9 The crisis sequence: The United States

Source: OECD Economic Outlook: Statistics and Projections (Database)

corporations and the rich. Furthermore, it inspired financial deregulation, or 'financialization' (Krippner, 2011), in an attempt to restart the capitalist growth engine, especially in Anglo-American countries. As we know now, this did not really work and growth rates under financialization continued to decline. In the end, when the strategy collapsed in the Great Recession, it turned out to have produced pseudo-growth at best.

Over time, insufficient growth gave rise to a sequence of different crisis configurations, with (i) high inflation and low debt in the 1970s followed, from 1980 to 1993 , by (ii) low inflation and public and private debt rising simultaneously, and from 1994 to 2007 by (iii) low inflation, receding public debt and further increasing private debt. Since 2008, we continue to see (iv) low inflation, now combined with slightly declining private debt and exploding public debt (Figure 9 for the US; the pattern for many other countries is essentially the same, with variations reflecting specific circumstances). Overall, growing public debt was part of a general rise of indebtedness in capitalist countries, which coincided with low growth and indeed may have been the result of attempts to sustain and restore economic performance ('Pumpkapitalismus') ${ }^{16}$. For example, the aggregate debt burden of the United States, comprising the debt of government, households and non-financial as well as financial corporations, doubled in four decades from four-and-a-half to nine times the country's GDP (Figure 10). Government debt accounted for just a very small share of this. The fact that the rise in government debt since the 1980s was embedded in a simultaneous rise in aggregate debt ${ }^{17}$ tends to be overlooked in discussions on the fiscal problems of

16. The term was coined by Ralf Dahrendorf in one of his last essays (Dahrendorf, 2009). See also Streeck $(2013,225 \mathrm{ff}$.).

17. The general picture remains the same if the debt of the financial sector is excluded. 


\section{W. Streeck}

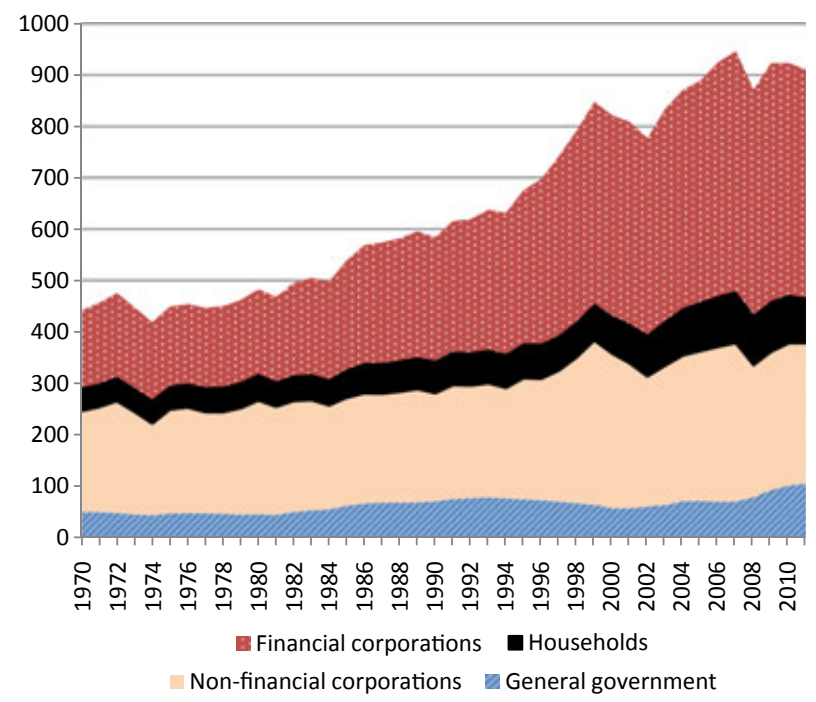

Figure 10 Liabilities as a percentage of GDP by sector, United States, 1970-2011

Source: OECD National Accounts Statistics (Database): Financial Balance Sheets - Non-consolidated stocks

contemporary democracies, in particular those that attribute such problems to a failure of democracy. Increasing overall indebtedness, which seems to have continued after 2008, would appear to represent an insufficiently understood aspect of contemporary capitalist development.

\section{REBUILDING CONFIDENCE}

The crisis of 2008, I suggest, marked the beginning of a new era in the politics of public debt, and generally in the relationship between global capitalism and the state system. As states accepted vastly increased indebtedness to rescue their national economies from the fallout of the collapse of the financial industry, investors in public debt appeared to become doubtful whether governments would ever be able to honor their unprecedented financial obligations, and whether public debt had reached a point where states would find it more in their interest to default than to pay up. Declining investor confidence found expression, among other things, in rising and unpredictably fluctuating risk premiums on government bonds and in a flurry of changing judgments meted out by the three US rating agencies. Not surprisingly, economists went to work to calculate the debt level beyond which a country would cease to be solvent in part because its debt would render its economy unable to grow (Reinhart and Rogoff, 2010). ${ }^{18}$

18. While there has been considerable excitement recently on a calculation error and the method of sample construction in Reinhart and Rogoff's 2010 study (Herndon et al., 2013), what should have caused consternation much earlier is their idea, mechanistic if nothing else, of a 'one size fits all' general debt threshold for all countries, regardless of political and economic circumstances - not to mention that high debt may be the effect of low growth rather than vice versa. 
It soon turned out, however, that the matter was more complicated. Apparently, if there was a critical threshold, it was different for different countries. The United States continues to be charged a risk premium close to what 'the markets' required from Germany, even though its government effectively refuses to address the country's decades-old 'double deficit'. Rather than specific numbers, discussions began to focus on intangibles like the trustworthiness of a country's politics and the confidence it inspired in the psychology of owners of financial assets. In a more technical language, what was looked for was credible commitments on the part of countries to servicing their debt, come what may. I suggest that it is in this context that the rise of austerity, as a political imperative for some - debtor countries, must be seen.

The politics of public debt may be conceived in terms of a distributional conflict between creditors and citizens (Streeck, 2013, 117-132). Both have claims on public funds in the form of contractual-commercial and political-social rights, respectively. In a democracy, citizens have the possible opportunity to elect a government responsive to them, but 'irresponsible' from the viewpoint of financial markets, in the extreme case a government that expropriates its creditors by annulling its debt. As accumulated debt increases and investors are required to be more careful about where they put their money, creditors will seek guarantees that expropriation will not happen to them - in effect, that their claims will always be given priority over those of citizens, for example, of pensioners demanding the pension that the state and employers promised them when they were workers.

'Structural reform' of domestic spending to cut the 'entitlements' of the citizenry is one important way of reassuring creditors that their money will be safe. ${ }^{19}$ Another is institutional change, such as a balanced budget amendment to the national constitution or international obligations to honor commercial before political, or explicit before implicit, debt. I consider extracting credible commitments of this kind - where there is broad space for creativity with respect to their concrete form ${ }^{20}$ - as the driving force of the transformation of the debt state of the last third of the twentieth century into the consolidation state of the future.

Looking at Europe, what is peculiar here is that what is to be the restoration of investor confidence is taking place not just in national but also in international politics through a deep restructuring of the European state system, as both the European Union and, in particular, European Monetary Union demand. To reassure creditors, states are agreeing to tight mutual surveillance, for example, under the Fiscal Pact, tying each other's hands to rule out default and to constrain one another in becoming fit for debt service. This involves far-reaching sacrifices of national sovereignty in exchange for arrangements amounting de

19. 'Lloyd Blankfein, the head of giant investment bank Goldman Sachs, has said the UK must stick with its austerity plan or face a negative reaction from global investors. In an interview with the $\mathrm{BBC}$, he said he would like it if the UK could ease the pace of the squeeze on spending. However, Mr Blankfein ... said if you have a deficit that choice is taken away from you because markets will react'. BBC News, 23 April 2013 (http://www.bbc.co.uk/news/business-22260949).

20. Means of restoring creditor confidence may include a low general level of public spending, low taxes and a lean state, a de-unionized economy, all major political parties subscribing to fiscal rectitude and committed to a healthy financial industry and the like. 
facto to a mutualization of public debt, guaranteeing bond holders that they will be paid even if a member state was to become insolvent. Since debt mutualization cannot be popular with voters in countries that would have to pay for it, it is typically done not in the light of day, but rather inside the entrails of the European central bank, whose President has famously vowed 'to do whatever it takes to preserve the euro'. ${ }^{21}$

How much and what kind of 'confidence' the 'markets' must be provided with by debt states is far from understood. Clearly, creditors will not complain if states, fearing the fear of the markets, do more than would in fact be necessary. Since international capital markets are not subject to competition law, it can also not be precluded that investors will collectively drive up the price of their trust. States, in turn, may use financial regulation to force certain categories of investors, like insurance companies, to buy and hold their bonds. The strategic games that are being played here will not end when the current crisis is declared over, if it ever is. States will for a long time be dependent on financial markets, even with consolidated finances, if only for refinancing their remaining debt (which will be considerable for many years even in the best of cases). In any case, financial markets may need government debt as a safe haven for investment. Bargaining over the rebuilding of the democratic state in the face of high debt, at the national as well as international level, will therefore not cease, with citizens trying to defend their social rights and creditors threatening higher risk premiums unless the primacy of their titles is firmly established in international treaties and national fiscal regimes and constitutions.

As is being noted, building investor confidence by way of imposing austerity on national economies may not in all circumstances achieve its objective. Austerity may impede economic growth by cutting demand, rather than promoting it by, among other things, creating 'rational expectations' on the part of the 'real economy' for low taxes and higher growth in the future. Apparently, as claimed by Blyth (2013) and others (Boyer, 2012), expansionary austerity has never really worked in a financial crisis. While austerity may shift an increasing share of a society's resources from citizens to creditors, it may shrink the sum total of available resources. Obviously the second effect could, in particular in the longer run, suppress the first effect as low growth might undo whatever confidence may have been gained through austerity.

\section{THE RISE OF THE CONSOLIDATION STATE}

Almost a century after Schumpeter's seminal study on the tax state, we are looking back at the rise and fall of that which had turned into a debt state in the 1980s, give way two decades later to that which today is shaping up as a consolidation state. Even more than before 2008 - the year when the financial crisis caused a lapse back into debt-making on a broad front - capitalist democracies are currently restructuring

21. 'Within our mandate, the ECB is ready to do whatever it takes to preserve the euro. And believe me, it will be enough'. Verbatim of the remarks made by Mario Draghi, at the Global Investment Conference in London, 26 July 2012. Website of the European central bank, http://www.ecb.int/press/key/date/2012/html/sp120726.en.html, read April 27, 2013. 
their public finances in a second wave of consolidation efforts to credibly restore their long-term capacity to provide safe investment opportunities to holders of financial assets, domestic as well as international. It is around this issue that the contemporary politics of rebuilding the state in rich capitalist countries revolves.

Governments striving to consolidate their finances aim above all at reducing their deficit ratios - the gap between expenditures and revenues in relation to GDP - to a level below the rate of growth of their national economies. A more ambitious and presumably more confidence-inspiring goal would be a balanced budget, or even a budget surplus by which to bring down the debt level even faster. ${ }^{22}$ While deficit reduction would of course be possible via tax increases, this is only rarely considered, except perhaps for social security or consumption taxes where the tax base is immobile. The implication is that consolidation by raising public revenues is likely to make tax systems more degressive. ${ }^{23}$ As noted, tax competition and evasion in particular of estate, income and corporate taxes, have been among the leading causes of public debt in the first place. ${ }^{24}$ However, unless all major countries act in unison, for example by jointly rolling back their tax reforms of the 1990s and 2000s, they would have to fear losing not just parts of their tax base but also investment and employment in their 'real economies' ${ }^{25}$

As a consequence, the preferred strategy of fiscal consolidation is cutting expenditures, retrenching state activities consistent with neoliberal standard recipes. The practical question here is the kind of expenditure governments can most afford to cut. Unlike the 1990s after the collapse of the Soviet Union, there is no longer much of a peace dividend to collect. The only major exception might be the United States, which spends more on defense than the rest of the world together. Still, the US seems unlikely to significantly reduce its defense spending, notwithstanding technological progress toward cheaper hardware like drones. $^{26}$ What remains, then, are cuts in either mandatory or discretionary public spending; the former being by definition more difficult to make than the latter, at least in the short term. Mandatory public spending encompasses citizen entitlements, mainly to social security and healthcare, as well as the salaries of public employees. Discretionary spending includes public investment in the physical infrastructure and social investment in education, science and technology, labor market policy, family services and the like (Streeck and Mertens, 2011).

22. Of course debt levels can also be lowered by fiscal repression (Reinhart and Sbrancia, 2011), combining over a lengthy period a - hopefully moderate - rate of inflation with low interest rates and some form of capital controls to oblige domestic owners of monetary assets to invest in national government bonds. However, this presupposes that investment capital can be held captive, or that the banking industry can be effectively regulated by the central bank.

23. This is why it may be difficult to do, likely as it is to cause voter resistance, especially at a time of privatization of government services and rising income inequality, with tax cuts for highincome earners and corporations remaining in place.

24. On tax evasion, see the documents gathered by the International Consortium of Investigative Journalists and made available in April, 2013: http://www.icij.org/offshore/secret-files-exposeoffshores-global-impact.

25. See the recent OECD declaration (2013).

26. In an important way, military strength helps turn the United States into a 'safe haven' for sovereign wealth from critical regions of the world, enabling its government to offer protection to sheiks and others in return for their purchase of US treasury bonds. 


\section{W. Streeck}

In the politics of the consolidation state, mandatory and discretionary spending tend to be played off against one another, typically in terms of a potential conflict of interest between the old, who insist on their entitlements from the past, and the next generation, who depend on public provision for their future. If the old are unwilling to make sacrifices for the young ${ }^{27}$ - or for the credibility of the state in the eyes of its creditors - they may be accused of egoism, which is in fact what is happening in many countries today. If bearers of social entitlements successfully resist cuts - which they are often able to because, among other things, they vote in larger numbers than other groups do (Goerres, 2009) discretionary spending will be cut more than mandatory spending. This would result in declining public investment and increasing privatization of government services. $^{28}$

Privatization was fashionable in the 1990s when the first attempts were being made to cut back the contemporary state. It is likely to continue in the second wave of consolidation. Privatization of education, pensions, childcare, etc. responds to the more individualized demand of a prosperous middle class and will often meet with their support. At the same time, privatization tends to occur with declining quality of the remaining government services on which less prosperous social groups will continue to depend (Mehrtens, 2013). This makes privatization likely to have negative effects on equality of opportunity and on the distribution of access to quality services unless there is deep government regulation of privatized services which, however, may drive investors away. As to physical infrastructures, privatization may take the form of increased reliance on private-public partnerships, something to which governments, in particular local governments, need to get used lest they fall prey to the sophisticated marketing and pricing practices of, often international, profit-making firms.

Privatizing former state functions opens markets and creates opportunities for capital accumulation; in this way it contributes to capitalist development and expansion. At the same time, it may disadvantage countries in need of attracting investment by offering superior public infrastructures, especially high-wage countries like Germany that have to make up for their disadvantage in labor costs. While tax competition limits public resources, competition for inward investment forces states to attempt diverting public spending away from social entitlements to infrastructural provision for internationally mobile producers. Whether this will work must remain open even in the longer term. In any case, as noted, economic growth has long been sluggish and has in the past two decades gone hand in hand with a continuous build-up of aggregate debt. Whether consolida-

27. Which is likely because cutting pensions or healthcare for them amounts to a refusal to pay them what in effect are deferred wages, and to honor a social contract guaranteeing workers the means to end their lives in retirement outside of poverty. There is also the implication that states, when they stepped in to make workers accept lower-than-living wages from their employers by promising to close the gap out of public funds during retirement, promised more than they could deliver, building up implicit government debt too big for governments to redeem. Fiscal consolidation by cutting mandatory government expenditure amounts to a downgrading of implicit state debt in relation to explicit state debt.

28. As we have shown using data from the first wave of consolidation in the 1990s, declining government expenditure tends to go together with disproportionate cuts in - discretionary - public investment, both physical and social (Streeck and Mertens, 2011). 
tion of public finances, with its detrimental effect not just on demand but also on public investment, ${ }^{29}$ will reverse this trend must appear questionable.

\section{PUBLIC DEBT AND SOCIAL INEQUALITY}

The build-up of public debt since the 1970s was connected in complex ways to the increase in economic inequality that was occurring at the same time, and this holds true also for the current politics of consolidation. As growth rates declined and unemployment became endemic in the OECD world after the end of inflation, the wage and income spread increased, and so did public spending. Dwindling unionization and the 'withering away of the strike' (Ross and Hartman, 1960) contributed their share to rising inequality in incomes (Western and Rosenfeld, 2011). Tax collection became more difficult due to growing resistance, and later also because of international tax competition in an increasingly open global economy. Public revenues fell as a result, further adding to public deficits and public debt. Distributional gains on the part of capital and of segments of the middle classes, made possible by a growing low-wage sector and less progressive taxation, produced a savings overhang that was looking for safe investment opportunities. Tax reforms aimed at dissuading firms and high earners from exiting to less demanding jurisdictions reinforced this, expanding both the demand for and the supply of sovereign credit. By the 1990s at the latest, governments found it necessary to allow the financial industry to expand far beyond traditional limits, among other things by creating new credit instruments benefitting states dependent on borrowing at favorable rates. Financialization in itself increased income differences, both between sectors and within (Palley, 2008; Tomaskovic-Devey and Lin, 2011).

States borrowing from their citizens instead of taxing them make another, independent contribution to economic and social inequality. Owners of financial assets who can lend to the state what it would otherwise have confiscated earn interest on what remains of their capital. They may also leave their wealth to their offspring, especially where inheritance taxes have been cut or abolished for fear of taxpayer exit. A similar effect, incidentally, is at work under 'privatized Keynesianism' where liberalized credit serves to replace social assistance or supplement low wage. The result is that the poor have to repay with interest what would have been their wage or social benefit with better employment, stronger trade unions and more public intervention (Mertens, 2014).

Moreover, as the debt state in its current form as a consolidation state reassures its creditors that their claims to public funds will take precedence over the claims of citizens, it is essentially expropriating social rights and politically created entitlements intended to contain inequality. Privatization of public services and a reduction in public social investment make for more unequal access to resources essential for equality of opportunity in an advanced 'knowledge society'. As a result, social mobility for future generations is likely to diminish, as is already the case in the United States (Karabel, 2012). With consolidation contin-

29. On the latter see the forthcoming doctoral dissertation by Lukas Haffert at the Max Planck Institute for the Study of Societies. 


\section{W. Streeck}

uing, patterns of public spending will follow tax systems in becoming less progressive.

\section{CONCLUDING REMARKS}

When Schumpeter first outlined his project of fiscal sociology, he was convinced that the tax state he had seen grow out of the old regime of feudal property would not last forever. This fate it would share with modern capitalism itself, a political-economic formation which, Schumpeter believed throughout his life, would in a not-so-distant future disappear, even though he kept changing his mind on what the cause would be. In 1918, Schumpeter seemed to have shared the then prevailing view that with social and industrial progress, modern societies would, as organized collectivities, have to take command of an ever-rising share of their economies. In this process, they would grow out of the system of private capitalism into a less competitive and more fraternal social order. ${ }^{30}$ Later, while he continued to expect capitalism - and with it the tax state - to come to an end, Schumpeter saw its impending demise less sanguinely, emphasizing factors such as the rise of 'coffee-house intellectuals' and social democratic mass parties together with the desire of a majority of voters for economic security to be delivered by an extensive ruling bureaucracy (Schumpeter, 1975 [1942]).

Whatever the details, it is worth emphasizing that the notion of a growing public sector constraining and eventually absorbing the private economy was almost commonplace among early theorists of capitalist development well into the twentieth century. Its most sophisticated expression it probably found in the Marxian figure of an increasingly social nature of production which - with a growing complexity of the division of labor and a correspondingly rising need for infrastructural support and political coordination - was bound to come into conflict with a regime of private ownership. This idea was, however, by no means restricted to Marxism. It was present also in the writings of the conservative Prussian Kathedersozialist, Adolph Wagner, with his conjecture, dubbed 'Wagner's Law' by others, of a tendency for the public economy, with the advance of 'civilization', to grow faster than its private counterpart (Wagner, 1892, 883ff.). It is against this background that current pressures for a curtailment of public involvement in the economy may usefully be assessed.

To begin with, it seems worth remembering that classical political economy entirely failed to foresee the rise of the civilian debt state that began in the 1970s and 1980s, and exactly the same holds for the neoliberal revolution that accompanied it. While the Marxist sociologist James O'Connor expected a 'fiscal crisis of the state' as early as the late 1960s (O'Connor, 1970a,b) - and was seconded in this by, of all people, his conservative antipode Daniel Bell (1976)

30. According to Schumpeter, once 'capitalism has done its work and an economy exists which is satiated with capital...', it will be 'possible to look forward calmly to that inevitable slowing down of merely economic development which is the concomitant of socialism, for socialism means liberation of life from the economy ... By and by private enterprise will lose its social meaning through the development of the economy and the consequent expansion of the sphere of social sympathy...' (Schumpeter, 1991 [1918], 131). 
- he never considered the possibility of a, however temporary, solution by public debt. But then nobody envisaged, not even in the final years of the Bretton Woods world in the 1970s, that democratic nation-states might suffer from a secular attrition of their sovereign power because of economic internationalization. Moreover, the turn to fiat money in the 1970s, which allowed new methods of monetary support for a capitalist economy increasingly torn by distributional conflict, was as unanticipated as the subsequent growth of a global financial industry of a dimension and, if this is the word, sophistication beyond anyone's imagination. Both the freeing of the money supply from the last remaining material restrictions and the global expansion and integration of money-making as an industrial activity helped, for some time, to paper over the increasing gap between, among other things, government expenditures and revenues.

What is coming? We have seen how the emerging consolidation state is cutting itself back through public austerity and the privatization of infrastructures and social services. The question is whether this will restore economic growth and secure democratic legitimacy for post-2008 capitalism. Seeking to achieve these goals as in the past two decades by relying on a lax monetary policy and a bloated financial sector, apt any time to produce new bubbles, may at best be risky and could easily become self-destructive when another 'rescue' like that of 2008 would be needed, but by then perhaps impossible (Stockman, 2013). The alternative, the neoliberal reform cure which requires stripping society of its remaining defenses and throwing it into the icy waters of an untamed market economy in the hope that it will eventually start swimming, may be rejected by the voting public as long as there still is one. The result may be a political standoff, as in Italy, which is unlikely to encourage economic growth either.

What if a resumption of growth, as implied by older traditions of political economy, requires more public investment rather than less, and perhaps also a reversal of the apparently inexorable trend toward ever more inequality (Stiglitz, 2012)? In this case, the declining capacity of politics to contain the plundering of the public sphere and the apparently unending self-enrichment of the already unendingly rich may pose a problem not just for democracy but also for the economy - look at the superrich among the Greeks who are abandoning Greece in droves, availing themselves of free international capital markets to take their money to the safe havens of Wall Street or the City of London; or the Russian and Ukrainian 'oligarchs' who, having expropriated their fellow citizens in post-communist primitive accumulation, are now abandoning them to their domestic misery. What we are seeing here may be the beginning of the fate of economic elites finally becoming divorced from the economies-cum-societies from where they derived their riches, decoupling the fortunes of the rich and their families from the prosperity, or the lack of it, of normal people.

Does this sound outlandish? Consider the current state of the distributional game in the United States, a country that, unlike Ukraine or China, is still considered a democracy by many. According to Emmanuel Saez, in 2010, the Year Two after the crisis, at a time of high unemployment and record public debt, 93\% of all income gains in the US, i.e., almost the entire amount by which the national income increased, went to the top one per cent of the income distribution. What is more, the top $0.01 \%$, about 15,000 households, received more than 


\section{W. Streeck}

a third, 37\%, of those income gains (Saez, 2012). ${ }^{31}$ There is no reason not to call this an asset stripping operation of epic dimensions perpetrated by a tiny minority benefitting, among other things, from the deepest tax cuts in history. Why should the new oligarchs be interested in their countries' future productive capacities and present democratic stability if, apparently, they can be rich without it, processing back and forth the synthetic money produced for them at no cost by a central bank for which the sky is the limit, at each stage diverting from it hefty fees and unprecedented salaries, bonuses and profits as long as it is forthcoming - and then leave their country to its remaining devices and withdraw to some privately owned island?

\section{ADDRESS FOR CORRESPONDENCE}

Wolfgang Streeck, Max Planck Institute for the Study of Societies, Paulstr. 3, 50676 Cologne, Germany. Tel.: +49 2212767 202; fax: +49 221 2767-402; e-mail: streeck@mpifg.de

\section{REFERENCES}

Bell, D. (1976) 'The Public Household: On 'Fiscal Sociology' and the Liberal Society', Ch. 6, in: D. Bell (ed.), The Cultural Contradictions of Capitalism, Basic Books, New York, pp. 220-282.

Blyth, M. (2013), Austerity: The History of a Dangerous Idea, Oxford University Press, Oxford.

Boyer, R. (2012), 'The Four Fallacies of Contemporary Austerity Policies: The Lost Keynesian Legacy', Cambridge Journal of Economics 36, 283-312.

Buchanan, J. M. (1958), Public Principles of Public Debt: A Defense and Restatement, Richard R. Irwin, Inc., Homewood, IL.

Buchanan, J. M., G. Tullock (1962), The Calculus of Consent: Logical Foundations of Constitutional Democracy, Univrsity of Michigan Press, Ann Arbor.

Buchanan, J. M., G. Tullock (1977), 'The Expanding Public Sector: Wagner Squared', Public Choice 31, 147-150.

Buchanan, J. M., R. E. Wagner (1977), Democracy in Deficit: The Political Legacy of Lord Keynes, Academic Press, New York.

Crouch, C. (2009), 'Privatised Keynesianism: An Unacknowledged Policy Regime', British Journal of Politics \& International Relations 11, 382-399.

31. As summarized by Steven Rattner in the New York Times, 25 March 2012: 'In 2010, as the nation continued to recover from the recession, a dizzying 93\% of the additional income created in the country that year, compared to 2009 - $\$ 288$ billion - went to the top one per cent of taxpayers, those with at least $\$ 352,000$ in income. That delivered an average single-year pay increase in $11.6 \%$ to each of these households. Still more astonishing was the extent to which the super rich got rich faster than the merely rich. In 2010, 37\% of these additional earnings went to just the top $0.01 \%$, a teaspoon-size collection of about 15,000 households with average incomes of $\$ 23.8$ million. These fortunate few saw their incomes rise by $21.5 \%$. The bottom $99 \%$ received a microscopic $\$ 80$ increase in pay per person in 2010 , after adjusting for inflation. The top one per cent, whose average income is $\$ 1,019,089$, had an $11.6 \%$ increase in income'. (http://www.nytimes.com/2012/03/26/opinion/the-rich-get-even-richer.html?_r = 0) 


\section{The Politics of Public Debt}

Dahrendorf, R. (2009) Vom Sparkapitalismus zum Pumpkapitalismus. Cicero online. 23. Juli 2009.

Duménil, G., D. Lévy (2004), Capital Resurgent: Roots of the Neoliberal Revolution, Harvard University Press, Cambridge, MA.

Genschel, P., P. Schwarz (2013), 'Tax Competition and Fiscal Democracy', in: A. Schäfer, W. Streeck (eds.), Politics in the Age of Austerity, Polity, Cambridge, pp. 59-83.

Goerres, A. (2009), The Political Participation of Older People in Europe: The Greying of Our Democracies, Palgrave Macmillan, Basingstoke.

Greider, W. (1981) The Education of David Stockman. The Atlantic, December 1981, http:// www.theatlantic.com/magazine/archive/1981/12/the-education-of-david-stockman/305760/. Accessed 22 July 2013.

Hacker, J., P. Pierson (2011), Winner-Take-All Politics: How Washington Made the Rich Richer - and Turned Its Back on the Middle Class, Simon \& Schuster Paperbacks, New York, NY.

Herndon, T., M. Ash and R. Pollin (2013) ,'Does High Public Debt Consistently Stifle Economic Growth? A Critique of Reinhart and Rogoff', Political Economy Research Institute Working Paper Series No. 322. University of Massachusetts Amherst, Amherst, MA.

Holtfrerich, C.-L. (2007), Wo sind die Jobs? Eine Streitschrift für mehr Arbeit, Deutsche Verlagsanstalt, München.

Judt, T. (2005), Postwar: A History of Europe Since 1945, Penguin, London.

Judt, T. (2009), 'What Is Living and What is Dead in Social Democracy?', The New York Review of Books, December 17, 2009, pp. 86-96. http://www.nybooks.com/articles/archives/2009/ $\mathrm{dec} / 17 /$ what-is-living-and-what-is-dead-in-social-democrac/?pagination=false. Accessed 22 July 2013.

Karabel, J. (2012), 'Grand Illusion: Mobility, Inequality, and the American Dream The Huffington Post'. http://www.huffingtonpost.com/jerome-karabel/grand-illusion-mobilityinequality-and-the-american-dream_b_1933238.html. Accessed 22 July 2013.

Kenworthy, L. (2007), Egalitarian Capitalism: Jobs, Incomes, and Growth in Affluent Countries, Russell Sage, New York, NY.

Kochan, T. A. (2013), 'The American Jobs Crisis and Its Implications for the Future of Employment Policy: A Call for a New Jobs Compact', International Labor Relations Review 66, 291-314.

Korpi, W. (1983), The Democratic Class Struggle, Routledge and Kegan Paul, London.

Krippner, G. R. (2011), Capitalizing on Crisis: The Political Origins of the Rise of Finance, Harvard University Press, Cambridge.

Kristal, T. (2010), 'Good Times, Bad Times: Postwar Labor's Share', American Sociological Review 75, 729-763.

Mehrtens, P. (2013), 'Staatsentschuldung und Staatstätigkeit: Zur Transformation der schwedischen politischen Ökonomie', Doctoral Dissertation. Universität Köln und MaxPlanck-Institut für Gesellschaftsforschung, Köln.

Mertens, D. (2014), 'Privatverschuldung in Deutschland: Zur institutionellen Entwicklung der Kreditmärkte in einem exportgetriebenen Wachstumsregime', Doctoral Dissertation. Wirtschafts- und Sozialwissenschaftliche Fakultät. Universität Köln und Max-PlanckInstitut für Gesellschaftsforschung, Köln.

Merton, R. K. (1968), 'The Matthew Effect in Science', Science 159, 56-63.

O'Connor, J. (1970a), 'The Fiscal Crisis of the State: Part I', Socialist Revolution 1, 13-54.

O'Connor, J. (1970b), 'The Fiscal Crisis of the State: Part II', Socialist Revolution 1, 34-94.

OECD (2013), Addressing Base Erosion and Profit Shifting, OECD, Paris.

Palley, T. I. (2008), 'Financialisation: What it is and Why it Matters', IMK Working Paper No. 4/2008. Institut für Markoökonomie und Konjunkturforschung, Düsseldorf. 


\section{W. Streeck}

Pierson, P. (1998), 'The Deficit and the Politics of Domestic Reform', in: M. Weir (ed.), The Social Divide: Political Parties and the Future of Activist Government, Brookings Institution Press and Russell Sage Foundation, Washington, D.C., New York, pp. 126-178.

Pierson, P. (2001), 'From Expansion to Austerity: The New Politics of Taxing and Spending', in: M. A. Levin, M. K. Landy and M. M. Shapiro (eds.), Seeking the Center: Politics and Policymaking at the New Century, Georgetown University Press, Washington, D.C., pp. 54-80.

Reich, R. B. (1997), Locked in the Cabinet, Knopf, New York.

Reich, R. B. (2007), Supercapitalism, Knopf, New York.

Reinhart, C. M. and K. S. Rogoff (2010), 'Growth in a Time of Debt', American Economic Review: Papers \& Proceedings. Vol. 100, 573-578.

Reinhart, C. M. and M. B. Sbrancia (2011), 'The Liquidation of Government Debt', NBER Working Paper Series No. 16893. National Bureau of Economic Research, Cambridge, MA.

Ross, A. M., P. T. Hartman (1960), Changing Patterns of Industrial Conflict, Wiley, New York.

Ruggie, J. G. (1982), 'International Regimes, Transactions and Change: Embedded Liberalism in the Postwar Economic Order', International Organization 36, 379-399.

Ryner, M. (2012), 'The (I)PE of Falling Wage-Shares: Situating Working Class Agency. Prepared for Presentation at the Inaugural Conference of the Sheffield Political Economy Research Institute (SPERI) 'The British Growth Crisis: The Search for a New Model' Sheffield', UK, July 17, 2012. Unpublished Manuscript.

Saez, E. (2012), 'Striking it Richer: The Evolution of Top Incomes in the United States (Updated with 2009 and 2010 estimates)'. http://elsa.berkeley.edu/ saez/saez-UStopin comes-2010.pdf. Accessed 22 July 2013.

Schäfer, A., W. Streeck (2013), 'Introduction', in: A. Schäfer, W. Streeck (eds.), Politics in the Age of Austerity, Polity, Cambridge, pp. 1-25.

Schratzenstaller, M. (2011), 'Vom Steuerwettbewerb zur Steuerkoordinierung in der EU?', WSI-Mitteilungen 64, 304-313.

Schratzenstaller, M. (2013), Für einen produktiven und solide finanzierten Staat. Determinanten der Entwicklung der Abgaben in Deutschland. Studie im Auftrag der Abteilung Wirtschaftsund Sozialpolitik der Friedrich-Ebert-Stiftung, Friedrich-Ebert-Stiftung, Bonn.

Schumpeter, J. A. (1975 [1942]), Capitalism, Socialism, and Democracy, Harper, New York.

Schumpeter, J. A. (1991 [1918]), 'The Crisis of the Tax State', in: R. Swedberg (ed.), The Economics and Sociology of Capitalism, Princeton University Press, Princeton, pp. 99-141.

Shonfield, A. (1965), Modern Capitalism: The Changing Balance of Public and Private Power, Oxford University Press, London and New York.

Shonfield, A., S. Shonfield (1984), In Defense of the Mixed Economy, Oxford University Press, Oxford.

Stiglitz, J. E. (2012), The Price of Inequality: How Today's Divided Society Endangers Our Future, W. W. Norton, New York.

Stockman, D. A. (1986), The Triumph of Politics: How the Reagan Revolution Failed, Harper and Row, New York.

Stockman, D. A. (2013), 'State-Wrecked: The Corruption of Capitalism in America', The New York Times Sunday Review, March 30, 2013. http://www.nytimes.com/2013/03/ 31/opinion/Sunday/sundown-in-america.html?pagewanted=all\&_r = 0. Accessed $22 \mathrm{July}$ 2013.

Streeck, W. (2011), 'The Crises of Democratic Capitalism', New Left Review 71, 5-29.

Streeck, W. (2013), Gekaufte Zeit: Die vertagte Krise des demokratischen Kapitalismus, Suhrkamp, Berlin.

Streeck, W., D. Mertens (2011), 'Fiscal Austerity and Public Investment: Is the Possible the Enemy of the Necessary?', MPIfG Discussion Paper No. 11/12. Max Planck Institute for the Study of Societies, Cologne. 
Streeck, W., C. Trampusch (2006), 'Economic Reform and the Political Economy of the German Welfare State', in: K. Dyson, S. Padgett (eds.), The Politics of Economic Reform in Germany: Global, Rhineland or Hybrid Capitalism? Routledge, Milton Park, Abingdon, pp. 60-81.

Thierry, B. (2005), 'Integrating proximate and ultimate causation: Just one more go!', Current Science 89, 1180-1184.

Tomaskovic-Devey, D., K.-H. Lin (2011), 'Income Dynamics, Economic Rents and the Financialization of the US Economy', American Sociological Review 76, 538-559.

Wagner, A. (1892), Grundlegung der politischen Oekonomie, Dritte ed., C. F. Wintersche Verlagshandlung, Leipzig.

Western, B. and J. Rosenfeld (2011) Unions, Norms, and the Rise in U.S. Wage Inequality. American Sociological Review 76, 513-537. 